\title{
Revistas femininas juvenis e a educação sexual no Ensino de Ciências
}

\author{
Female juvenile magazines and sexual education Inscience Education
}

\author{
${ }^{1}$ Bartira dos Reis Rocha Cezar \\ ${ }^{2}$ Eliane Portes Vargas
}

\begin{abstract}
RESUMO
Neste trabalho enfocamos as possibilidades de uso de revistas femininas juvenis em uma atividade nãoformal relacionada à educação sexual para o ensino de ciências. Destacando-se a temática da iniciação sexual na abordagem da sexualidade buscamos articular o conhecimento dos alunos sobre corpo, gênero e sexualidade tendo como mediadoras das atividades as revistas Capricho e Atrevida. A análise, apoiada na perspectiva socioantropológica, se beneficia de referenciais teóricos dos campos da comunicação e da educação para a articulação entre os conhecimentos dos jovens e o uso das revistas em sala de aula. A abordagem da sexualidade na escola comumente centrada na fisiologia e prevenção às DST mostrou-se, a partir da metodologia adotada, potencialmente ampliada ao abarcar aspectos subjetivos da sexualidade juvenil. Os resultados discutem a relevância do incremento de ações desta natureza para o ensino de ciências na medida em que considera na construção do conhecimento sobre a fisiologia dos corpos, no que tange à sexualidade, os saberes dos alunos e as mediações culturais presentes também na leitura das revistas.
\end{abstract}

Palavras chave: Ensino de Ciências, Mediações Culturais, Sexualidade.

\section{ABSTRACT}

In this paper we focus on the possibilities of using juvenile women's magazines in an activity related to nonformal sex educationfor science teaching. Highlighting the issue of sexual initiation in sexuality approach we intend to articulate what students know about the body, gender and sexuality as mediators of activities taking magazines Capricho and Atrevida.The analysis, based on the social anthropological perspective, benefits from theoretical fields of communication and education for the articulation between the knowledge of young people and the use of magazines in the classroom. The approach of sexuality in school commonly focused on physiology and STD showed up from the methodology adopted, potentially expanded to cover subjective aspects of teenage sexuality. The results question the relevance of the actions of this nature increment for science education in that it considers the construction of knowledge about the physiology of the body, in relation to sexuality, knowledge of students and cultural mediations also present in the reading of magazines.

Keywords: Science Education, Cultural Mediation, Sexuality.

1 Jornalista, Mestre em Ciências.

2 Doutora em Saúde Coletiva., pesquisadora do Instituto Oswaldo Cruz/Fiocruz. 


\section{INTRODUÇÃO}

Este trabalho ${ }^{3}$ tematiza as construções sociais e culturais de corpo, sexualidade e gênero entre jovens escolares mediadas pelas revistas femininas juvenis Capricho e Atrevida ${ }^{4}$ no contexto do ensino de ciências em uma escola pública estadualna Baixada Fluminense, Rio de Janeiro. Os alunos que participaram voluntariamente da pesquisa cursavam o $8^{\circ}$ ano do Ensino Fundamental, com idades entre 12 e 16 anos $^{5}$. Os tempos de aula e o acesso aos alunos, para o desenvolvimento das atividades, foram franqueados pela professora de ciências.O estudo focaliza a iniciação sexual como parte de um processo relevante na experiência da sexualidade juvenil repleta de sentidos para os jovens, como observado na produção discursiva desta temática amplamente retratada nas revistas femininas juvenis de grande expressão e circulação nacional. Assim, apresentaremos uma breve descrição do processo de construção do Plano de Atividade "Revistas Femininas Juvenis como Recurso Didático"a partir do uso contextualizado das revistas Capricho e Atrevida, como recurso adicional a ser explorado na abordagem de temáticas relacionadas ao corpo, à sexualidade e ao gênero no ensino de ciências. Em seguida, discutiremos os resultados da leitura crítica das revistas empreendida pelos alunos e as reflexões produzidas sobre as possibilidades e potencial de uso desta estratégia no ensino não-formal de Ciências buscando um diálogo com o professor de modo a subsidiar as práticas neste campo.As questões centrais ao estudo surgiram a partir de uma perspectiva crítica dos meios de comunicação,acerca do lugar ocupado pelas revistas femininas juvenis na construção do conhecimento sobre corpo e sexualidade na formação de suas identidades, e na percepção do interesse feminino na leitura de revistas com este perfil a elas direcionado; em especial, da organização discursiva que as tornavam referências em potencial para esclarecimentos de dúvidas que inauguram a experiência da sexualidade.

Esta investigação se insere no escopo de uma atividade de educação não-formal ${ }^{6} e$ torna-se relevante problematizar as fronteiras, nem sempre claramente delimitadas, entre este tipo de atividade e aquela denominada de ensino formal. Tendo em vista os elementos constitutivos desta última cabe considerar as múltiplas possibilidades oferecidas pelas atividades não-formais em educação para o aprendizado de temas, sobretudo daqueles relacionados às biociências e saúde. O contexto escolar se constitui no lugar onde potencialmente estas atividades se imbricam e se desenvolvem, mas não sem desafios como apontado pela literatura sobre o tema.

Segundo Palhares (2009) as reflexões acerca das contribuições do não-formal para a educação formal apontam que a incorporação das práticas não-formais nas atividades de ensino são alguns dos grandes desafios da educação na contemporaneidade. Os limites entre formal e não-formal se mostram muito tênues, pois observa-se dentro da escola coexistirem saberes e práticas que transitam entre os espaços fronteiriços delimitados entre o que se denomina formal e não-formal. A proposição, de superação destes limites, redefine a escola como espaço propício à multiplicidade da experiência de aprendizado diversificado e enriquecimento cultural (PALHARES, 2009). Nesta direção, Ghon (2006), informa que umas das características da educação não-formal se manifesta na "aprendizagem de conteúdos que possibilitem aos indivíduos fazerem uma leitura do mundo do ponto de vista da compreensão do que se passa ao redor” (p. 28). Uma das reconhecidas contribuições metodológicas da educação não-formal consiste na construção e reconstrução de concepções sobre o conhecimento que jovens escolares apreendem da realidade e da cultura a qual pertencem (GHON, 2006). Com esta perspectiva os métodos de abordagem para a educação não-formal se organizam a partir da problematização da vida cotidiana dos educandos,

3 O presente artigo corresponde a uma versão ampliada do trabalho aceito para apresentação no IX Encontro Nacional de Pesquisa em Educação em Ciências (ENPEC).

4 Os resultados deste estudo são parte da dissertação de mestrado sob a orientaçãoda Dr ${ }^{\mathrm{a}}$ Eliane Portes Vargas, desenvolvido no Programa de Pós-graduação em Ensino em Biociências e Saúde, apoio CAPES.

5 Sob o protocolo de número 600/11 esta pesquisa foi aprovada pelo Comitê de Ética em Pesquisa (CEP), após apreciação do colegiado por atender às exigências as diretrizes da Resolução 196/96 do Conselho Nacional de Saúde (CONEP).

6 A delimitação do estudo ao contexto do ensino não-formal se justifica pelo tipo de organização do Programa de Pós-graduação em Ensino em Biociências e Saúde, ao qual se insere caracterizada por duas áreas de concentração: Ensino formal e Ensino não -formal que se diferencia pela maior ou menor implicação do objeto de investigação com a sala de aula. Portanto, a diferenciação entre ensino formal e não-formal visa delimitar a natureza das investigações e às linhas de pesquisa na qual se filie o estudo, o que constitui, por sua vez, a identidade do Programa. 
permitindo a sistematização de uma metodologia de trabalho, para a formação de sujeitos conscientes, capazes de questionar realidades e práticas sociais na construção de novos valores no exercício da cidadania (GHON, 2006).

A capacidade de apreensão e a contextualização dos conhecimentos adquiridos na escola e na vida cotidiana são parte das premissas que orientam o estudo respaldado, por sua vez, nos Parâmetros Curriculares Nacionais (PCN) que inserem a Orientação Sexual como tema transversal dado a sua complexidade sociocultural. Além disso, e não menos relevante, consta dos Parâmetros como recomendação importante a ser considerada "a construção permanente de uma metodologia participativa que envolve lidar com dinâmicas grupais (...) possibilitando a discussão dos valores (sociais e particulares) associados a cada temática da sexualidade” (BRASIL, p. 47, 1997). A previsão desse tipo de prática educacional para a sexualidade em âmbito escolar preconiza o desenvolvimento de projetos e aplicação de metodologias em diálogo direto com os alunos para a discussão de outros aspectos da sexualidade que normalmente não são problematizados no ensino formal (BRASIL, 1997). Mas esta, na prática, nem sempre se efetiva ou mesmo tem sido contemplada nos estudos da área. Em revisão da literatura realizada nas Atas do VII ENPEC, ocorrido no ano de 2009, pôde-se observar as contribuições dos estudos que tematizam o corpo, gênero e a sexualidade no ensino de ciências indicando os esforços empreendidos por educadores na adoção de práticas não-formais na educação sexual de jovens. Identificou-se, no entanto, a quase inexistência de trabalhos dedicados a descrever como essas abordagens podem potencialmente ser incorporadas ao ensino das biociências e saúde.

A presença da escola e da mídia no cotidiano dos jovens como fonte para buscarem suas primeiras informações a respeito de relação sexual, gravidez/contracepção e DST/Aids já foram indicadas em outros estudos. Dados da pesquisa (GRAVAD, 2006) ${ }^{7}$, por exemplo, apontaramos meios de comunicação como relevante fonte para as primeiras informações sobre sexualidade entre jovens entrevistados no Rio de Janeiro. A escola e a televisão são as fontes mais citadas entre jovens de camadas populares na busca por informações sobre sexualidade. Entre jovens provenientes das classes mais privilegiadas $60 \%$ das mulheres jovens mencionam a mãe e $41 \%$ citam a escola como informação consistente (BOZON e HEILBORN, p. 160, 2006). Dentre as mulheres, em geral, 22\% declararam buscar na mídia (televisão, revistas femininas e masculinas) suas primeiras informações sobre relação sexual. Entre os homens este percentual representou 26\% para o conjunto das mídias. Um dado instigante pode ser mencionado: as revistas femininas e os serviços de saúde, com percentuais próximos, foram mencionados por mulheres jovenscariocas como as primeiras fontes de informação sobre relação sexual e gravidez/contracepção. A saber, quando perguntadas sobre onde obtiveram as primeiras informações sobre DST/Aids, observa-se um empate entre os serviços de saúde e as revistas femininas, com 12\% cada uma. Com relação à escola, $28 \%$ das mulheres informaram ser esta responsável pela disseminação de informações sobre relação sexual; 34\% sobre gravidez/contracepção e 56\% sobre DST/Aids (ibid., p.160, 2006). Entre os homens os amigos figuram como a mais citada fonte de informação sobre relação sexual, com 42\%.Com relação às DST/Aids, as fontes "serviços de saúde" e "revistas masculinas" obtiveram percentual igual sendo mencionadas por $4 \%$ dos entrevistados. Enquanto a escola representa para 50\% dos homens um espaço para obtenção de informação sobre DST/Aids. Entre as mulheres, este índice chega a 56\%, para aquisição de informações e prevenção às DST/Aids (ibid., p.160, 2006).

Observa-se, complementarmente, que as práticas de educação sexual na escola têm sido historicamente objeto de ações educativas no campo da saúde, o que torna a sexualidade problematizada a partir das doenças que a envolve. Considerando as fronteiras existentes nestas ações um especial interesse em promover o diálogo entre a escola e os serviços de saúde pode ser observado nas discussões sobre o tema. Nesta direção, a expectativa de que a escola desempenhe essa função na educação sexual dos jovens integra um projeto de controle social da sexualidade incidindo, em especial, sobre as práticas de iniciação. A gravidez e o risco das Doenças Sexualmente Transmissíveis (DST), se tornam os principais alvos de preocupações e intervenções dos educadores (ALTMANN, 2007). Assim, a escola é reconhecida como ambiente favorável às ações de Educação em Saúde

7 A pesquisa multicêntrica sobre Gravidez na Adolescência (GRAVAD) foi realizada em 2002 com jovens de três capitais brasileiras: Porto Alegre, Rio de Janeiro e Salvador. A interpretação dos dados da pesquisa quantitativa e qualitativa considerou na análise das concepções e práticas dos jovens acerca do tema, dentre outros aspectos, a escolaridade do pai e da mãe, o que resulta em diferenças relativas à classe social. 
por cultivar nos alunos hábitos que contribuam para a promoção, manutenção ou a recuperação da saúde da comunidade localizada em torno do território escolar (LEONELLO e L'ABBATE, 2006). Isto inclui a identificação dos sintomas das doenças, e características das DST, aspectos da reprodução e o uso dos métodos contraceptivos que exige abordagem diferenciada de modo a proporcionar uma maior ampliação de conhecimentos dos jovens sobre as mudanças corporais que acarretam transformações profundas nas percepções dos mesmos em relação ao outro e à realidade social. Ademais, o entendimento de que a exploração de temáticas próximas à experiência da iniciação sexual esteja proposta para o conjunto das disciplinas curriculares, a ênfase deste tipo de abordagem recai no ensino de ciências.

\section{O desenho do estudo e os caminhos da pesquisa: referenciais teórico-metodológicos}

Na construção das estratégias metodológicas e análise dos dados, delineadas por meio de uma abordagem qualitativa, foram desenvolvidas a análise da produção das revistas Capricho e Atrevida e uma descrição detalhada dos caminhos percorridos na pesquisa. Esta descrição, a um só tempo, corresponde ao desenho metodológico e os resultados obtidos discutindo as possibilidades de usos no ensino de ciências ao mostrar as diferentes etapas percorridas na construção metodológica. O sequenciamento das atividades desenvolvidas compreendem sinteticamente as seguintes etapas: 1) Caracterização e análise das revistasCapricho e Atrevida; 2) Atividade do “Saco sem-vergonha” e “O que é sexualidade?”; 3) “Produção de Cartazes”; 4) Grupos de Discussão. A sequência na qual a metodologia se estruturou atende aos pressupostos teórico-metodológicosdos Estudos de Recepção ${ }^{8}$ visando apreender o processo comunicativo de produção-circulção-consumo dos meios de comunicação.

Dessa forma, a Caracterização e Análise Crítica das revistas Capricho e Atrevida correspondem, dentro da perspectiva teórica dos Estudos de Recepção, à análise da produção. Ou seja, refere-se à primeira etapa da pesquisa, com a interpretação dos discursos sociais que os emissores põem em circulação socialmente, e as representações que os mesmos produzem, realizadaatravés da análise de fragmentos das revistas. As atividades“ $\mathbf{O}$ que é sexualidade?” e "Saco sem-vergonha” foram pensadas como as primeiras estratégias de aproximação com os alunos, após as primeiras observações e notas etnográficas sobre as interações dos alunos nas aulas de ciências. A primeira consistia em pergunta aberta para que os alunos pudessem exprimir livremente as opiniões sobre o tema. A segunda consistia na elaboração de perguntas dos alunos sobre quaisquer dúvidas que tivessem sobre sexualidade. As respectivas dúvidas foram depositadas sem identificação em um saco de tecido e retomadas nas atividades subsequentes. A atividade desenvolvida para a recepção das revistas, denominada "Produção de Cartazes”, representa o momento que os alunos puderam ler, manusear, recortar as revistas, e produzirem as suas próprias interpretações em diálogo com as mesmas e com as dúvidas sobre sexualidade elaboradas durante a atividade do “Saco sem-vergonha”. Os Grupos de Discussão objetivaramaprofundar as concepções e conhecimentos dos alunos representados nos cartazes em que as revistas foram mediadoras na expressão desse conhecimento.

Tendo em vista a análise da percepção dos escolares acerca do corpo e gênero na formação de suas identidades sexuais mediante a leitura das revistas Capricho e Atrevida, o estudo apoia-se em reflexões desenvolvidas nos campos da Comunicação Social, com o aporte teórico-metodológico dos Estudos de Recepção (MARTíN -BARBERO, 2003) e da Educação (FREIRE, 1979); articulados à perspectiva Socioantropológica (BOZONe HEILBORN, 2006) utilizando a etnografia para descrever o contexto escolar dos jovens e a construção das atividades de interação com as revistas femininas juvenis, bem como a apreensão de suas percepções e conhecimentos. Atividades com caráter eminentemente educativo convergem com uma concepção do processo comunicativo, onde os sujeitos participam ativamente na construção de conhecimentos juntamente com o professor que, dessa perspectiva, passa a desempenhar a função de mediador (FREIRE, 1979). A proposta educacional de

8 A perspectiva teórica dos Estudos de Recepção adotada nesta pesquisa, concebendo o receptor como coprodutor dos sentidos sociais, baseada no modelo teórico dos Cultural Studies estabelece uma relação entre comunicação e cultura sendo imprescindível considerar o contexto sociocultural dos sujeitos para a compreensão de como se dá o processo de recepção dos meios de comunicação. 
Freire se concretiza em premissas da dialogicidade entre o conhecimento do educador e do educando para que se estabeleça uma relação comunicativa operando transformações na realidade social através da educação. O conceito de mediação (MARTÍN-BARBERO, 2003) que integra a perspectiva na qual concebemos Capricho e Atrevida, as insere em uma rede de significados também composta pela escola, a família e os pares.Fazendo-nos supor que a discursividade sobre os eixos da vida amorosa sustentados pelos meios ocupam um lugar de destaque no imaginário juvenil. A apreensão da realidade, ou dos elementos da cultura que fazem parte da vida cotidiana dos sujeitos cognoscentes, estabeleceria esse primeiro contatopara a situação de comunicação no processo educativo: o diálogo (FREIRE, 1979).

Como aporte para a constituição da análise das concepções dos alunos trabalhamos com perspectivas construtivistas dos saberes acerca de corpo e gênero no âmbito da cultura, compondo as dimensões simbólicas que convergem para o referente 'corpo'.O processo de socialização da experiência corporal se dá ainda na infância quando a criança tem as suas primeiras experiências sensoriais tomando consciência do mundo a sua volta ao ver e ser tocado por outros. Através do corpo a criança tem condição de imersão no campo simbólico da cultura onde se desenvolve (LE BRETON, 2011; HEILBORN, 1997; LOURO, 2010). A socialização do corpo é, portanto, uma constante no desenvolvimento humano. As classificações sociais que incidem sobre o corpo como a infância, adolescência, fase adulta, são marcos para a compreensão das transformações fisiológicas sofridas pelo corpo ao longo dos anos. "Assim, o corpo não é somente uma coleção de órgãos arranjados segundo leis da anatomia e da fisiologia. É, em primeiro lugar, uma estrutura simbólica, superfície de projeção passível de unir as mais variadas formas culturais” (LE BRETON, p. 29, 2011).

O caráter de aprendizado da sexualidade ganha contornos mais acentuados na fase da adolescência, período de transição entre a infância e a vida adulta, quando os jovens são “convidados” a terem as suas primeiras experimentações sexo-afetivas com um parceiro. "O aprendizado constitui-se na familiarização de representações, valores, papéis de gênero, rituais de interação e de práticas, presentes na noção de cultura sexual”(HEILBORN, p.35, 2006). A adolescência seria, portanto, uma interpretação, uma forma de nomeação cultural para as transformações psicossociais pelas quais passam os jovens, deflagradas pelo crescimento do corpo e amadurecimento das funções reprodutivas.

Através do corpo também podemos identificar as representações de gênero classificadas pelas diferentes culturas nas distintas formas de enunciação do feminino e masculino. Os corpos constituem uma referência de identidade de gênero, que nem sempre serão correspondentes à distinção anatômica (ter pênis ou vagina) ou o desejo sexual, embora seja no corpo biológico que são estabelecidos os limites para a expressividade sexual (LOURO, 2010; WEEKS, 2010).

Aheterossexualidade normativa designa o estabelecimento de parâmetros sociais para a experiência da sexualidade considerada "natural” ou "normal” na comparação com a homossexualidade classificada como uma forma "anormal” de expressão do desejo entre pessoas do mesmo sexo (WEEKS, 2010). O modelo heterossexual que impõe um padrão de normalidade ocorre em oposição à homossexualidade e às expressões de feminilidades (LOURO, 2010). Assim, a perspectiva da sexualidade como fruto de um aprendizado sociocultural, nos permitiria questionar e desnaturalizar as relações sexo-afetivas concebidas como inatas na cultura.

\section{RESULTADOS E DISCUSSÃO}

\subsection{Caracterização das revistas e aspectos da produção relacionados à iniciação sexual}

Considerando a importância da pesquisa documental realizada para uma reflexão sobre os usos dos meios nas atividades de ensino, apresentaremos a seguir breve caracterização e análise de fragmentos das revistas Capricho e Atrevida. Os textos selecionados se referem aos arranjos culturais de socialização e na sexualidade, tais como o primeiro beijo, "a primeira vez", o namoro e o "ficar”. Nesta etapa do estudo percurso selecionamos exemplares publicados no primeiro semestre de 2011 de Capricho e Atrevida, totalizando 12 revistas. As edições 
utilizadas da revista Capricho (1114; 1116; 1118; 1120; 1122; 1124), e as edições da revista Atrevida (197; 198; 199; 200; 201; 202) correspondem aos exemplares vendidos no primeiro semestre de 2011.

A revista Capricho é a publicação mais antiga e mais vendida do país no segmento teen. O seu surgimento data da década de 50 e seu formato de fotonovela estava em consonância com as demandas das jovens da época interessadas no romantismo presente nestas narrativas. Com circulação média de 167.629 sua vendagem encontra-se distribuída respectivamente entre as classes A: 8\%; B:41\%; C: 46\% e D: 5\%. Sendo 89\% de leitores do sexo feminino e $11 \%$ do sexo masculino. Cerca de $65 \%$ do total de leitores estão na mesma faixa etária dos adolescentes que participaram da pesquisa na escola, ou seja, alunos do $8^{\circ}$ ano do ensino fundamental. Desses, 25\% dos leitores têm entre 10 a 14 anos e 40\% entre 15 a 19 anos (PUBLIABRIL, 2011).

Em terceiro lugar no ranking de vendas entre as publicações do seguimento, a revista Atrevida possui tiragem de 231 mil exemplares e com periodicidade mensal, estima-se que essa publicaçãoalcance aproximadamente 1.400.000 leitores em todo o país (REVISTA ATREVIDA, 2012). Ao contrário de Capricho em que não se têm registros de leitores provenientes da classe E, a revista Atrevida detém 7\% dos leitores das classes D e E. Enquanto o seu maior percentual se concentra nas classes B: 40; C: 46\%. O maior percentual etário se concentra entre os adolescentes de 10 a 14 anos com 28\% e entre 15 a 19 anos com 38\% dos leitores (REVISTA ATREVIDA, 2012). Predominantemente feminina os homens representam apenas $5 \%$ do total de consumidores da revista, quase a metade de leitores do sexo masculino verificado pela revista Capricho.

Capricho e Atrevidacomparativamente detêm respectivamente 8\% e 7\% de vendas provenientes da classe A. As classes B e C são as de maior concentração de leitores, totalizando 87\% em Capricho e 86\% em Atrevida. Contudo, somente a revista Atrevida possui leitores nas classes D e E, com 7\% das vendas nesta faixa. Enquanto para Capricho a classe D representa 5\% do seu público, sem registro de vendas na classe E. Estes dados sugerem que a similaridade de conteúdo e consumo reforçado nas revistas produz mais identificação com hábitos e valores das camadas médias ( $\mathrm{B}$ e C), do que nas classes A e D/E. A proximidade do percentual de vendagem entre as classes A e D/E, em especial em Atrevida, sugere que os mesmos padrões de consumo ou valores, estão aquém das demandas das classes $\mathrm{A}$, e distantes da realidade sociocultural dos jovens das classes $\mathrm{D}$ e $\mathrm{E}$.

Mediante o exposto, os quadros sinópticos, como ilustrados abaixo, integram o conjunto total das descrições sistematizadas a partir da leitura crítica das revistas; representando o primeiro instrumento de coleta de dados realizado no estudo. A distribuição das matérias em categorias analíticas, para fins de análise dos fragmentos das revistas, surgiram a partir da revisão de literatura buscando trabalhos anteriores (FIGUEIRA, 2003; FREIRE FILHO, 2006; GELATTI e AMARAL, 2009; MIRANDA-RIBEIRO e MOORE, 2002) que tiveram como objeto a revista Capricho e/ou suas congêneres. A saber, as categorias utilizadas: a) "Conquista Amorosa”, b) "Relacionamento Afetivo" e c) "Práticas Sexuais”, possibilitaram a classificação dos textos extraídos primeiro nessas categorias citadas e em seguida dispostas em quadros descritivos propiciando a interpretação dos dados selecionados. As categorias e quadros apresentados foram inspiradas na pesquisa de Daniela Barsotti Santos ${ }^{9}$

9 Dissertação intitulada: “Ideais de mulher: Estética, visão de corpo e de relações afetivo-sexuais veiculados pela mídia escrita em revistas direcionadas ao público jovem no contexto brasileiro". Dissertação apresentada à Faculdade de Filosofia, Ciências e Letras de Ribeirão Preto da USP, defendida no ano de 2006, 370 páginas. 
Quadros 1, 2 e 3: Fragmentos extraídos da Revista Capricho

Quadro 1: Revista Capricho

\begin{tabular}{|c|c|}
\hline 1. Categoria & Conquista Amorosa \\
\hline 2. Título & “Como ser inesquecível”. \\
\hline 3.Temática & $\begin{array}{l}\text { Dicas para que a menina saiba como falar e se comportar para que conquiste o } \\
\text { menino. }\end{array}$ \\
\hline 4.Descrição & $\begin{array}{l}\text { Texto escrito em tópicos e com um depoimento de um ator adolescente que está } \\
\text { fazendo sucesso na novela Ti-ti-ti. }\end{array}$ \\
\hline 5.Trecho do Texto & $\begin{array}{l}\text { “Caras também adoram sentir que estão mandando bem! Por isso, nem pense } \\
\text { duas vezes: se você adora as músicas que ele ouve, elogie e peça ao garoto que } \\
\text { prepare uma seleção musical para seu ipod”. }\end{array}$ \\
\hline 6.Tipo de texto & Texto enunciado em tópicos, com características prescritivas. \\
\hline $\begin{array}{lr}\text { 7.Fontes ronsultadas } \\
\text { (Discurso do especialista) }\end{array}$ & $\begin{array}{l}\text { Dalila Magarian, autora de “A Mulher Irresistível” e Fabiano Rampazzo, autor } \\
\text { de “Xaveco.com”. }\end{array}$ \\
\hline $\begin{array}{l}\text { 8. Análise da produção } \\
\text { textual }\end{array}$ & $\begin{array}{l}\text { O texto é ambíguo ao sugerir certa passividade feminina na conquista do parceiro. } \\
\text { Ao mesmo tempo em que incentiva que a jovem tome a iniciativa na hora da } \\
\text { conquista. Mas sendo cuidadosa para não ser muito explícita e se expondo } \\
\text { desnecessariamente. A revista apresenta um discurso polifônico nesse sentido. } \\
\text { Quando é possível identificar prescrições na conduta feminina, de modo que } \\
\text { não se exponha no exercício da sua sexualidade para que não sofra preconceitos } \\
\text { sociais por não ser mais virgem. }\end{array}$ \\
\hline
\end{tabular}

Fonte: Capricho, Conversa de Banheiro, Jan. 2011, no 1114, p. 80.

Quadro 2: Revista Capricho

\begin{tabular}{|l|l|}
\hline 1. Categoria & Práticas Sexuais \\
\hline 2. Título & "Rolou e agora?” \\
\hline 3.Temática & Primeira relação sexual das meninas. \\
\hline 4.Descrição & $\begin{array}{l}\text { Trata-se de um texto com ilustrações onde é apresentado o resultado de uma } \\
\text { enquete feita com 16.156 meninas. }\end{array}$ \\
\hline 5.Trecho do Texto & $\begin{array}{l}\text { "Pedir em namoro depois de ter transado não é uma obrigação do garoto na } \\
\text { opinião de 42\% das meninas.” }\end{array}$ \\
\hline 6.Tipo de texto & Texto enunciado em tópicos apresentando o resultado de uma enquete. \\
\hline $\begin{array}{l}\text { 7.Fontes consultadas } \\
\text { (Discurso do especialista) }\end{array}$ & João Borzino, sexólogo e terapeuta sexual. \\
\hline textual & $\begin{array}{l}\text { O texto é marcado pela forma que trata a primeira relação sexual da menina } \\
\text { como um assunto apenas íntimo e pessoal delas, que não envolve o menino. Este } \\
\text { discurso sugere a normatização dos relacionamentos e reforça a impossibilidade } \\
\text { de diálogo entre o casal. Sugere ainda ser aceito como normal que a menina ceda } \\
\text { à pressão para manter relações sexuais sem ter certeza do que quer, não trazendo } \\
\text { apontamentos sobre a autonomia feminina sobre o próprio corpo. }\end{array}$ \\
\hline
\end{tabular}

Fonte: Capricho, Sexo, Jan. 2011, $n^{\circ} 1114, p .81$ 
Quadro 3: Revista Capricho

\begin{tabular}{|l|l|}
\hline 1. Categoria & Relacionamento Afetivo \\
\hline 2. Título & "Meu irmão é gay”. \\
\hline 3.Temática & Preferência sexual. \\
\hline 4.Descrição & $\begin{array}{l}\text { Um pedido de ajuda enviado por uma adolescente de 15 anos. Na qual se lê } \\
\text { a opinião de um adolescente que é gay, de uma menina que viveu situação } \\
\text { semelhante e de um especialista (psicólogo) que procura tranquilizar a menina. }\end{array}$ \\
\hline 5.Trecho do Texto & $\begin{array}{l}\text { "Descobri que meu irmão é gay. O namorado dele é um garoto que sempre vem } \\
\text { aqui em casa e sou a única da família que sabe. Não sou preconceituosa, mas } \\
\text { estou achando difícil aceitar essa ideia”. }\end{array}$ \\
\hline 6.Tipo de texto & Texto com ilustrações. \\
\hline $\begin{array}{l}\text { 7.Fontes consultadas } \\
\text { (Discurso do especialista) }\end{array}$ & $\begin{array}{l}\text { Claudio Picazio, psicólogo e autor de livros sobre sexualidade. Cecília Oshiro, } \\
19 \text { anos e Guilherme Gonçalves, 16 anos, gay. }\end{array}$ \\
\hline $\begin{array}{l}\text { 8. Análise da produção } \\
\text { textual }\end{array}$ & $\begin{array}{l}\text { O destaque desse texto é que aborda a homossexualidade. Sua abordagem é um } \\
\text { esboço do que poderia ser uma importante discussão do tema na revista, pois traz } \\
\text { opiniões variadas. }\end{array}$ \\
\hline
\end{tabular}

Fonte: Capricho, Terapia, Mar. 2011, no 1118, p. 66.

Quadros 4, 5 e 6: Fragmentos extraídos da Revista Atrevida

Quadro 4: Revista Atrevida

\begin{tabular}{|c|c|}
\hline 1. Categoria & Conquista Amorosa \\
\hline 2. Título & “Jogo do amor colorido”. \\
\hline 3.Temática & $\begin{array}{l}\text { Como conquistar os ídolos da banda Restart, outro famoso ou qualquer galã da } \\
\text { escola. Afinal, esses garotos são mais especiais ainda, segundo sugere o texto. }\end{array}$ \\
\hline 4.Descrição & Matéria com seis páginas, com fotografias e ilustrações. \\
\hline 5.Trecho do Texto & $\begin{array}{l}\text { "Descolar um namorado nem sempre é fácil. Rock star, então... Se você curte um } \\
\text { famoso ou está a fim do galã da escola, precisa se jogar na conquista de cabeça”. }\end{array}$ \\
\hline 6.Tipo de texto & Texto prescritivo, normativo, curto e em tópicos. \\
\hline $\begin{array}{l}\text { 7.Fontes consultadas } \\
\text { (Discurso do especialista) }\end{array}$ & Texto de Marcia Barreto em colaboração de Aline Marchiori. \\
\hline $\begin{array}{l}\text { 8. Análise da produção } \\
\text { textual }\end{array}$ & $\begin{array}{l}\text { Nesta tem-se a conjugação da conquista amorosa com a prescrição feita pelos } \\
\text { garotos que também são ídolos. Ou seja, sugere que se a garota souber como } \\
\text { conquistar um ídolo, um menino em tese mais difícil por ser muito cobiçado, } \\
\text { também poderá conquistar os mais bonitos da escola. }\end{array}$ \\
\hline
\end{tabular}


Quadro 5: Revista Atrevida

\begin{tabular}{|l|l|}
\hline 1. Categoria & Práticas Sexuais \\
\hline 2. Título & “Quase lá”, “Insistente”, "Menstruação e gravidez”. \\
\hline 3.Temática & Dúvidas sobre sexo e sexualidade. \\
\hline 4.Descrição & Virgindade (primeira vez), gravidez e menstruação. \\
\hline 5.Trecho do Texto & $\begin{array}{l}\text { "Eu e meu namorado já tentamos transar duas vezes, mas não conseguimos. } \\
\text { Eu estava relaxada, tranquila e segura do que queria. Mas, mesmo assim, não } \\
\text { aconteceu. “O problema é comigo ou com meu namorado?”. }\end{array}$ \\
\hline 6.Tipo de texto & $\begin{array}{l}\text { O texto tem o formato de perguntas enviadas por e-mail anonimamente, e com as } \\
\text { respostas subsequentes. }\end{array}$ \\
\hline $\begin{array}{l}\text { 7.Fontes consultadas } \\
\text { (Discurso do especialista) }\end{array}$ & $\begin{array}{l}\text { Dra Carolina Carvalho Ambrogini, ginecologista e coordenadora do Projeto } \\
\text { Afrodite de Sexualidade Feminina, da Unifesp. }\end{array}$ \\
\hline $\begin{array}{l}\text { 8. Análise da produção } \\
\text { textual }\end{array}$ & $\begin{array}{l}\text { O texto esclarece as dúvidas e tranquiliza as leitoras, nesta edição também } \\
\text { recomenda que a menina procure um ginecologista. }\end{array}$ \\
\hline
\end{tabular}

Fonte: Atrevida, Comportamento, \#Tudo_sobre_sexo, Fev. nº198, p.18.

Quadro 6: Revista Atrevida

\begin{tabular}{|l|l|}
\hline 1. Categoria & Relacionamento Afetivo \\
\hline 2. Título & "Quero ser notada!”, “Autoavaliação”, "Vale a pena esperar?”. \\
\hline 3.Temática & Amizade, namoro, ficar. \\
\hline 4.Descrição & $\begin{array}{l}\text { A coluna traz mensalmente a três perguntas sobre relacionamentos que uma } \\
\text { especialista responde. }\end{array}$ \\
\hline 5.Trecho do Texto & $\begin{array}{l}\text { "O ciúme em excesso é o principal ingrediente para estragar qualquer } \\
\text { relacionamento. Mas quando ele vem com o machismo e o orgulho... socorro!!! } \\
\text { Talvez ajude você saber que nós, mulheres, somos “enganadas” desde muito } \\
\text { pequeninas. E sabe de quem é a culpa? Dos contos de fadas (...) Ele só vai } \\
\text { mudar "se” e "quando” ele quiser”. }\end{array}$ \\
\hline 6.Tipo de texto & $\begin{array}{l}\text { Texto escrito em tópicos e com ilustrações. Uma menina toda 'fashion’ falando } \\
\text { no megafone em frente a um tênis masculino gigante. Dando a entender como as } \\
\text { mulheres ainda estão em desvantagem com relação aos homens e que talvez ela } \\
\text { precise falar mais alto para ser ouvida. }\end{array}$ \\
\hline $\begin{array}{l}\text { 7.Fontes } \\
\text { (Discurso do especialista) }\end{array}$ & $\begin{array}{l}\text { Prof. Dra Lilian Graziano, psicóloga e doutora em Psicologia pela USP; psicóloga } \\
\text { clínica e diretora do Instituto de Psicologia Positiva e Comportamento. }\end{array}$ \\
\hline $\begin{array}{l}\text { 8. Análise da produção } \\
\text { textual }\end{array}$ & $\begin{array}{l}\text { Nesta edição a especialista construiu uma resposta pouco habitual das que } \\
\text { comumente circulam na Atrevida. Sua postura foi a de provocar reflexões e } \\
\text { questionamentos nas meninas sobre os papéis de gênero e expectativas nos } \\
\text { relacionamentos. Esta seção produziu respostas bastante interessantes. }\end{array}$ \\
\hline
\end{tabular}

Fonte: Atrevida, Comportamento, \#ficadas e_rolos, Mar. $n^{\circ} 199$, p.18.

As reflexões produzidas referem-se aos fragmentos extraídos das edições de maio/2011, das seções sobre sexo de Capricho e Atrevida. As análises revelaram a predominância de temáticas que fazem referência à iniciação tais como o primeiro beijo, a "primeira vez" e o namoro. Assuntos concernentes aos modos de introdução nos relacionamentos sexuais-afetivos eram recorrentes em seções como: "Ficadas e Rolos" de Atrevida ou "Sexo" na Capricho. 
As primeiras leituras de Capricho e Atrevida revelaram que, embora as marcas discursivas da iniciação sexual possam incidir em muitas das suas páginas, assuntos como namorar, ficar, primeiro beijo ou a 'primeira vez’, têm seu lugar nas seções das revistas.

As seções sobre sexo das duas revistas se distinguem muito no formato. Em Atrevida prima-se pelo diálogo com as leitoras ao propor, com a ajuda de especialistas, responder às dúvidas enviadas por e-mail, trazendo ainda resultados de enquetes destinadasàs leitoras. Na explanação, uma leitora pede a seguinte orientação: “(...) Gostaria de saber se falar com o namorado sobre isso ajuda ou prejudica (porque causa muita expectativa)”. A médica chama a atenção para o cuidado de não expor a sua intimidade nas redes sociais e completa: "E se não for sua intenção transar agora, fique atenta, porque com essas conversas você pode gerar expectativas em seu namorado” (REVISTA ATREVIDA, maio, 2011, p. 18).

A postura da especialista é de desencorajar a leitora a falar sobre sexo com o namorado, caso ela ainda não tenha decidido ter relações sexuais. Nesse sentido, a intenção da leitora de conversar sobre sexo com o namorado, destoa parcialmente com as conclusões a que chegaram um estudo de Heilborn e Bozon (2006) que indica haver diferenças de gênero na vivência da primeira relação sexual com parceiro denotando uma passividade das mulheres ao dizerem não pensar muito sobre sexo. Isto pode "convergir para uma representação "espontaneísta” da relação sexual, que se produziria sem que nenhum dos dois tivesse verdadeiramente pensado nela” (p.183). Embora a jovem intencione conversar sobre sexo ela se mostra hesitante com sua prática discursiva, recorrendo então, à Atrevida em busca de respostas não logrando, no entanto, plena aceitação por parte da médica que a advertiu dos perigos em se provocar os meninos quando o assunto é sexo. Esta intervenção presente na narrativa da especialista reproduz neste caso a ideia presente no senso comum acerca do impulso sexual como inato.

Na Capricho a sexualidade é tratada em percentuais com resultados obtidos de enquetes feita com as leitoras através do seu site, essas questões são abordadas na seção denominada "Sexo". No texto "Ele quer, eu não!” (REVISTA CAPRICHO, maio, 2011), o título denota a virgindade como um valor por parte dos especialistas ao aconselhar que a menina respeite o seu tempo e não ceda à pressão do menino. "Se você está sendo pressionada, não ceda só porque ele quer. Senão você pode se arrepender depois. Converse com o menino e reforce o quanto gosta dele, mas explique que não quer transar ainda” (REVISTA CAPRICHO, maio, 2011, p. 73). Isso demonstra que a perda da virgindade é aceita desde que seja com a pessoa certa. A não aceitação do menino na negativa das meninas em transar significa que ele não é a pessoa certa; ficando sob a responsabilidade feminina preservar a castidade ou arcar com as consequências de seus “erros”.

A análise dos fragmentos das seções sobre ‘sexo' contidos nestes dois exemplares permitiu identificar algumas das principais construções discursivas acerca de corpo e gênero, bem como as possíveis reverberações desses discursos nas concepções dos alunos na formação das suas identidades na perspectiva das relações de gênero. Cabe observar a ausência de uma menção à pluralidade e à diversidade sexual, quando, por exemplo, somente foram selecionadas as dúvidas de casais heterossexuais. Considerando as atuais mudanças nas transformações das relações familiares e da legislação específica a favor dos novos arranjos familiares a observação nos parece pertinente.

\subsection{Sexualidade e gênero: mediações culturais e possibilidades de abordagens no ensino}

As diferenças de gênero na busca por informações sobre a sexualidade é um ponto a ser observado na adoção da metodologia de trabalho com as revistas. Enquanto as meninas declararam recorrer às revistas femininas juvenis para sanarem suas dúvidas sobre as práticas sexuais, os meninos preferem buscar o conhecimento nas revistas masculinas tais como Playboy ou Sexy. Os alunos reconheceram as limitações das revistas quando afirmaram não serem boas fontes de informação sobre sexualidade. No entanto, apesar das críticas dos alunos ao conteúdo das revistas é inegável que a linguagem empregada neste recurso é atrativa para os jovens. 
Eu não gostei da revista, não. Porque não fala nada sobre o homem, sobre o homem não tem (GUILHERME, 14 anos).

Nem todas são boas pra informação. Às vezes elas têm perguntas que as meninas não estão muito interessadas. Por exemplo, tem algumas que são legais, aquela da primeira vez que vai fazer sexo. Se uma pessoa vai ficar nervosa porque vai fazer sexo pela primeira vez, pode buscar essa informação, entendeu? Já é uma informação pra ela, porque ela envolve uma experiência, que já entende do assunto (ERIC, 14 anos).

Essas revistas falam mais de homens famosos, né? Eu acho que essas revistas não são boas, porque o certo é elas falarem de todo tipo de menino. Menino que tem dinheiro, menino feio, bonito. Falar de todos os modos de meninos que existem, mas elas não falam, só falam de meninos ricos e bonitos (FABIANO, 13 anos).

Nesse sentido, identifica-se uma lacuna por parte dos meios ao tratar aspectos intrínsecos à sexualidade masculina, sugerindo uma vertente de gênero a ser explorada no âmbito da educação sexual. A partir dessa ausência identificamos ser possível explorar nas relações de gênero a perspectiva masculina, provocando questionamentos acerca da abordagem realizada pelas revistas. O profesor, através da resposta dos alunos às atividades, poderá escolher como melhor explorar as concepções dos mesmos mediante a leitura e reelaboração dos discursos das revistas. Assim como os alunos criticam as revistas também apontam as limitações da metodologia de ensino formal que, nesta escola, estava centrada no uso do livro didático. Segundo Fischer (2002) os recursos utilizados por vários meios de comunicação, e também presentes nas revistas femininas juvenis, "funcionam para capturar a intimidade de um sujeito que sofre, chora, emociona-se ou demonstra culpa (...), mesmo que por rápidos instantes, efetivamente penetrar na intimidade daquele que fala e (...), também na intimidade daquele que "especta”, daquele que olha (p.157). Assim, podemos supor que a linguagem empregada pelas revistas e transpostas nas atividades, foi um diferencial mais de uma vez apontado pelos alunos para justificarem o interesse e a ampliação de conhecimentos sobre as práticas sexuais.

Conforme as análises críticas sobre o tema, as revistas expressam uma gama de exemplos de reforços de estereótipos de gênero e sexualidade. Por isso, ressalta-se a importância de leituras prévias do material a ser introduzido para sua seleção (textos ou seções) a serem trabalhados. É fundamental que o educador saiba quais aspectos conceituais e concepções deseja enfatizar, ao longo do trabalho. Embora este estudo não tenha contemplado o conteúdo do ensino de ciências trabalhado no $8^{\circ}$ ano do Ensino Fundamental, considera-se ser viável uma maior articulação deste conteúdo introduzido pelo livro didático; a fim de que o professor na atividade realizada com as revistas, identifique as recorrentes concepções equivocadas que surjam sobre reprodução, DST, orientação sexual, dentre outros.

Assim, o professor não apenas exerceria a função de mediador das discussões deflagradas com as revistas, mas também desempenharia a função de organizador das mesmas em torno dos elementos centrais aosconteúdos necessários para a apreendizagem do temas pelos alunos contribuindo para a ampliação de sua abordagem. O processo educativo, seja nas práticas de ensino ou através dos usos dos meios de comunicação, se apresenta aos professorespermeado por questões culturais, de reconhecimentos, de mediações e de negociações entre os alunos para a construção de novos saberes (FREIRE, 1979; MARTÍN-BARBERO, 2003). Nesse sentido, Martín-Barbero (1995) enfatiza que a popularização das tecnologias da informação não garante a independência e altivez de pensamento, de modo a formar gerações mais conscientes ou reflexivas. Segundo o autor um mercado editorial segmentado, representa a fragmentação do habitat cultural, demarcando através da produção de informação nos meios, as relações de poder; estabelecendo diferenciações entre a informação para a tomada de decisões e a informação para a massa populacional, visando o entretenimento. Ou seja, a diferenciação feita através dos meios de comunicação na distribuição do capital do conhecimento cria uma hierarquia social nas instâncias de poder, restringindo a participação social na cultura. 
A distribuição dos conhecimentos que tecem as realidades sociais é hierarquizada, e o acesso à informação por si só não nos assegura a criticidade, cabendo à instituição escolar oportunizar uma leitura crítica acerca dos processos envolvendo os meios de comunicação e difusão da informação. O desafio está em não restringir as propostas ao acesso à informação, mas em questionar as estruturas de poder na sociedade e dentro da escola, que se organizam a partir de novas possibilidades de comunicação e educação.A dificuldade demonstrada pela professora de ciências em lidar com as demandas dos alunos durante as aulas sobre o tema foi percebida por eles como apontado por uma aluna. Ressalta-se a importância da atuação da escola na educação sexual escolar:

Eu acho que aqui na escola precisava ter mais atividades que falem para os homossexuais. Aqui na escola têm muitos que sofrem muito preconceito. Até os professores têm preconceito (MONIQUE, 15 anos).

Estudos indicam a presença de práticas discriminatórias por parte dos professores, como um indício de lacunas na formação (ROHDEN, 2009). O reconhecimento de que alguns educadores manifestam seus preconceitos com relação a orientação sexual, isto não significa que as dificuldades enfrentadas em sala de aula pelo professor se deva somente a lacunas na sua formação. Embora a percepção dos alunos seja válida. Apontar a formação continuada como a principal "falha” nos sistema educacional, apenas toca tangencialmente uma questão que requer uma discussão mais aprofundada no âmbito das políticas públicas da educação.

Com base nestes resultados a metodologia de trabalho apresenta-se potencialmente como um recurso adicional no auxílio ao educador/professor na identificação dos pontos que os alunos mais têm dúvidas, e como estas se sobrepõem ao conhecimento científico exprimindo lacunas no aprendizado e nos conteúdos curriculares previstos. Como a participação do professor não estava prevista, não será possível discutir como a introdução desta metodologia poderia contribuir, do ponto de vista do educador, para a consolidação e aumento de conhecimento dos alunos envolvidos no estudo. Contudo, para os alunos as atividades com as revistas se mostraram fundamentais para sua motivação em aprofundar os conhecimentos adquiridos nas aulas de ciências, uma vez que o conteúdo das aulas era retomado pelos mesmos na forma de dúvidas emergentes no "Saco sem-vergonha" e trabalhadas na sequência da atividade.

Eu acho que deu pra aprender sim. Igual a mim, eu fiz várias perguntas (no saco sem-vergonha), nem todas foram equalizadas, mas quando eu estava fazendo o trabalho eu fui a várias mesas, tinham perguntas interessantes, e aí eu li e memorizei as respostas. Li as respostas dos colegas e achei legal (FABIANO, 13 anos).

As possibilidades de incorporação desta metodologia no ensino formal de ciências não fizeram parte dos objetivos deste estudo e permanece no horizonte de possibilidades de abordagem sobre o tema. As análises têm sugerido que a integração dos saberes científicos ao contexto sociocultural dos jovens reforça o caráter de aprendizado da sexualidade que para a assimilação de conceitos e conteúdos requer atenção aos aspectos subjetivos intrínsecos às práticas sexuais, em especial no período da iniciação sexual. Assim, destacamos a relevância de atividades não-formais no ensino de ciências para contemplar a educação sexual dos estudantes sendo necessária a ampliação do debate para além do aprendizado e prevenção das DST e gravidez na adolescência, como temas prevalentes neste âmbito. Assim, consideramos constituir-se um desafio para o ensino das biociências a conjugação do conteúdo formal disposto no livro didático com atividades não-formais, como aqui descrita, que vise ampliar a educação sexual escolar dando relevância aos aspectos subjetivos da sexualidade.

Os modos de enunciação da diversidade sexual emCapricho e Atrevida nos permite concluir que as poucas páginas dedicadas ao tema contribuem para que se reforcem estereótipos quanto ao gênero e à orientação sexual. Enunciado como um padrão de normalidade as revistas reiteram um modelo cultural de heterossexualidade como único para a entrada na sexualidade (WEEKS, 2010; LOURO, 2010). Esses modelos se espalham por todo o conteúdo das revistas, desde as fotos de casais formados por homens e mulheres aos textos correspondentes às imagens. O tratamento que as revistas dão à homossexualidade confere uma conotação de tema extraordinário ou de desvio à normalidade. 
No que se refere aos usos das revistas quando o assunto é a homossexualidade os alunos demonstraram ter uma opinião bastante contundente sobre a pouca importância dada a este tema nas páginas de Capricho e Atrevida. Nos exemplares analisados há o registro de dois textos que trataram sobre homossexualidade. O primeiro está na Capricho do mês de março na seção Terapia "Meu irmão é gay”, traz o seguinte depoimento de uma leitora de 15 anos:

Descobri que meu irmão é gay. O namorado dele é um garoto que sempre vem aqui em casa e sou a única da família que sabe. Não sou preconceituosa, mas estou achando difícil aceitar essa ideia. Meus pais desconfiam e minha mãe diz que esse seria um grande desgosto para ela. Já quis conversar com o meu irmão, mas não tenho coragem. O que eu faço? (REVISTA CAPRICHO, 2011, Março, p. 66).

O tratamento da revista dado ao "problema" partilhado reúne a opinião de um psicólogo, um jovem homossexual e uma jovem que relata ter vivido experiência semelhante. A seguir trechos retirados dos três depoimentos contidos na matéria da Capricho:

É normal que esse segredo torne sua conversa com seu irmão mais difícil. Provavelmente, ele acha que deve esconder a sexualidade de todos por medo de não receber apoio (CLAUDIO PICAZIO, Psicólogo, REVISTA CAPRICHO, março, p. 66, 2011).

Tem certeza de que não é preconceito? Você disse que não tem coragem de conversar com ele (...) Lembre-se de que a personalidade do seu irmão continua a mesma independentemente da orientação sexual dele, ou seja, não existem motivos para vocês se afastarem (CECÍLIA OSHIRO, 19 anos, REVISTA CAPRICHO, março, p. 66, 2011).

Se você já sabe desse segredo, isso quer dizer que tem menos motivos para se sentir confusa com relação a ele. Quando estiverem sozinhos, comente sobre algum garoto bonitinho, por exemplo. Pode até colocar um 'né?’ no final, para ver o que ele diz, rsrs. Mas não vale forçar a barra! Se esse comportamento não rolar de forma natural, provavelmente só vai deixá-lo chateado ou irritado (GUILHERME GONÇALVES, 16 anos, gay, REVISTA CAPRICHO, 2011, março, p. 66).

Na edição do mês de abril Atrevida trouxe a seguinte dúvida de uma leitora que suspeita de que uma de suas melhores amigas esteja seduzindo-a:

Minha amiga quer que eu pare de ficar com um garoto, sem motivo algum, e ela fica meio que me seduzindo. Estou achando que ela é homossexual, mas eu não quero falar sobre isso com ela, para não ser indelicada. Não quero perder a amizade, mas também não quero ficar com ela. O que eu faço? (REVISTA ATREVIDA, Impondo Limites, 2011, abril, p. 20).

A resposta da revista vem através da consultora da seção “Ficadas e Rolos”, a psicóloga Lilian Graziano, aconselha a menina (idade não informada) a impor os seus limites:

Antes de dizer a ela, com todas as letras, que não está à vontade com a situação, você pode, por exemplo, demonstrar desaprovação a cada atitude dela na qual você perceber essa intenção de sedução. Se ela olhar pra você com segundas intenções, por exemplo, diga: "Não gosto quando me olha desse jeito. Sinto-me desconfortável”. Se, mesmo depois de falar isso algumas vezes, diferentes situações, ela continuar insistindo, aí sim você precisará ser mais direta. E não se preocupe: a indelicadeza será dela, e não sua, por ter imposto seus limites (REVISTA ATREVIDA, abril, 2011, p. 20).

Com este posicionamento observamos que as revistas abordaram a homossexualidade da perspectiva dos heterossexuais, e com uma abordagem médica ao eleger profissionais de saúde para falar sobre o tema. A exceção é a matéria da Capricho que buscou ouvir a opinião de um homossexual para falar de como a jovem poderia enfrentar o próprio preconceito, mas esta não foi direcionada para uma problematização da homofobia. 
Questionados sobre as poucas matérias que informassem sobre a homossexualidade e sobre quais assuntos gostariam de poder ler mais nas revistas os alunos se posicionaram:

Eu acho que não apareceu nas revistas por uma palavra: preconceito. Eu acho que as pessoas não querem colocar sobre homossexualismo nas revistas pra não prejudicar. Os meninos e as meninas homossexuais leem as revistas, mas não acham nada sobre eles. (FERNANDO, 12 anos).

Há revistas que têm. Que eu já vi falando sobre homossexuais, na Loveteen eu já li sobre. Tem depoimentos deles. Mas na Capricho e na Atrevida eu nunca vi (LUIZA, 14 anos).

Eu acho que podia falar mais sobre homossexualidade, para as pessoas conhecerem mais, e aceitarem mais. Sobre anticoncepcional, camisinha. As revistas que eu li falam mais assim: "ah, como encontrar o parceiro certo" ou "teste de namoro”, mas não falam muito sobre doenças, como prevenir (TATIANE, 15 anos).

Como usar também (a camisinha). Algumas pessoas têm dúvidas, vergonha de perguntar, mas procuram nas revistas, mas às vezes não têm. Também sobre remédios, anticoncepcionais (MARIA EDUARDA, 15 anos).

O caráter compulsório da heterossexualidade se expressa na escassez de questionamentos sobre as funções sociais desempenhadas pelos sexos feminino e masculino, predominando um discurso naturalizado, sugerindo que homens só podem sentir desejo por mulheres e vice-versa. A intolerância ou aversão à homossexualidade se traduz nacontraposição da identidade masculina entre os jovens brasileiros (HEILBORN, CABRAL, BOZON, 2006); significando uma ameaça à masculinidade muita proximidade a este universo teorizado em seus discursos como algo bem distante das suas realidades, conforme se posicionaram na ausência de homossexuais em suas classes escolares. Percepção esta que também justifica, na perspectiva dos alunos, à pouca importância dada pelas revistas ao tema da homossexualidade. As percepções em especial das alunas sobre o que buscam nas revistas e as lacunas das informações não encontradas nos meios de comunicação demonstram como estão sendo usadas e de que forma compõem os cenários das práticas, exercendo muitas vezes, a função de informar os jovens sobre sexualidade. Mesmo que as revistas estejam mais reforçando estereótipos do que discutindo a diversidade sexual e gênero, demonstraram exercer uma função pedagógica entre os jovens. Observamos descompassos entre os discursos enunciados e a vivência dos jovens ao demandarem questões, pertinentes às suas realidades e práticas, que extrapolaram as discussões contempladas nas revistas, que por vezes demostraram resistências em diversas temáticas; marcando uma postura mais conservadora.

\section{CONSIDERAÇÕES FINAIS}

Durante o desenvolvimento do estudo buscamos manter o foco na contribuição das atividades não-formais para o ensino de ciênicas, e as variações possíveis para melhor subsidiar o aprendizado dos alunos despertando o seu interesse no conhecimento científico através das experiências cotidianas pertencentes à realidade desses jovens escolares. Assim, pudemos observar a presença dos elementos da cultura sexual popular nas representações dos alunos, na releitura das revistas, bem como as tradições e influências culturais em muitos momentos se sobrepõem aos conceitos científicos dos processos corporais implicados, em especial quanto à reprodução e às DST. A maioria declarada de leitoras das revistas foram as meninas, independente da etapa de iniciação sexual na qual se encontravam. Apesar disso, os meninos demonstraram ter bastante clareza sobre o porquê do interesse das meninas nesse tipo de publicação e como o retrato masculino enunciado nas revistas não condiz com a realidade deles, não somente financeira, mas também de representação de si por "venderem” um modelo de masculinidade muito idealizado.O lugar das revistas na rede comunicativa desses jovens é periférico assumindo um caráter complementar em seus saberes. Os dados apontam a importância atribuída pelos alunos à escola para se informarem sobre sexualidade, modos de prevenção à gravidez e/ou às DST. Embora as revistas, bem como 
outros meios de comunicação e redes de relações, como a famíliae os pares, constituam fontes de informações acessadas pelos jovens, é na escola que eles depositam suas melhores expectativas quando desejam aprofundar os seus conhecimentos ou confirmar novos saberes adquiridos na vivência cotidiana.

A consolidação do Plano de Atividade "Revistas Femininas Juvenis como Recurso Didático” se apresentou frutífera na abordagem da temática do estudo e potencialmente viável para o aprendizado do conteúdo formal de ciências (previsto no currículo) acerca do corpo humano e sexualidade, a ser explorado pelo educador. Haja vista que esta consolidação se deu durante os Grupos de Discussão mediante as justificativas dos jovens por suas escolhas ou opinões quando recorriam aos conhecimentos adquiridos em sala de aula. Ressalta-se nas concepções dos jovens acerca da sexualidade que os principais questionamentos estiveram relacionados às relações de gênero e a reprodução, superando a preocupação com as DST. As atividades com as revistas também representaram, segundo a percepção dos próprios alunos, uma oportunidade de retomar os conteúdosde ensino de modo mais próximo de suas realidades, reforçando a complementariedade das atividades formais e não-formais no ensino-aprendizado das biociências.Estivessem essas revistas reforçando ou não estereótipos, as motivações dos jovens em lê-las indicou a possibilidade de uma aproximação dos conhecimentos nestas modalidades de ensino.

As representações produzidas pelos alunos reforçaram a importância do empenho do sistema educacional em aperfeiçoar o uso de metodologias no ensino de ciências que busquem usar com criticidade os meios de comunicação, de modo a pluralizar e legitimar outras formas de conhecimento. Com relação aos conteúdos tratados nas atividades, em especial aquelas referentes à reprodução e à negociação e uso do preservativo, estes poderiam ser ampliados visando o aperfeiçoamento de abordagens da sexualidade no que tange aos conteúdos de fisiologia. Assim, alguns conhecimentos dos alunos pouco contemplados ao longo do desenvolvimento das atividades com as revistas podem servir aos professores de oportunidade no que tange à abordagem do conteúdo formal de ciências.

Por esta razão, defendemos o uso contextualizado das revistas femininas juvenis como parte do ensino de ciências, seja ele integrado ou não a uma atividade educativa formal. Com vistas a articular o conhecimento científico e popular para a promoção não somente do aprendizado dos processos corporais que, sem dúvida despertam o interesse dos alunos, mas também para o entendimento de questões culturais que concorrem para as atitudes, comportamentos e aprendizado, contribuindo para a dissolução de preconceitos e estereótipos que persistem não só entre os profissionais incumbidos da tarefa de ensinar, mas também entre as novas gerações de escolares.

\section{REFERÊNCIAS}

ALTMANN, H.Educação sexual e primeira relação sexual: entre expectativas e prescrições. Estudos Feministas, Florianópolis, v.15, n.2 p. 333-356; 2007a.

BOZON, M.; HEILBORN, ML. "Iniciação à Sexualidade: Modos de Socialização, Interações de Gênero e Trajetórias Individuais”. In: HEILBORN, MLet al (org.). O Aprendizado da Sexualidade: reprodução e trajetórias sociais dos jovens brasileiros.Rio de Janeiro: Garamond e FIOCRUZ. 2006, p.155-202.

BRASIL. Secretaria de Educação Fundamental. Parâmetros Curriculares Nacionais: apresentação dos Temas Transversais, ética. Brasília: MEC/SEF, 1997.

FIGUEIRA, Márcia Luiza Machado. "A revista Capricho e a construção de representações de feminilidade adolescente". In: CONGRESO IBEROAMERICANO DE HISTORIA DE LA EDUCACIÓN LATINO AMERICANA, 6., 2003, San Luis Potosí. p. 1-14. Disponível em: <http://boletimef.org/biblioteca/2383/ Revista-Capricho-e-a-construcao-de-representacoes-de-feminilidade>. Acesso em: 12 nov. 2010.

FISCHER, R.M.B. O dispositivo pedagógico da mídia: modos de educar na (e pela) TV. Educação e Pesquisa. São Paulo, v. 28, n. 1, 2002. Disponível em: <http://www.scielo.br/scielo.php?script=sci_arttext\&pid=S151797022002000100011\&lng=en\&nrm=iso>. Acesso em: 15 de março de 2012. 
FREIRE, Paulo. Extensão ou Comunicação? Tradução de Rosisca Darcy de Oliveira [prefácio de Jacques Chonchol] 4.ed.Rio de Janeiro: Paz e Terra,1979.

FREIRE FILHO, João. Em Cartaz, as garotas superpoderosas: a construção discursiva da adolescência feminina na revista Capricho. Revistas Fronteiras-estudos midiáticos. V.VIII (2). Maio/agosto 2006.

GELATTI, Juliana Reichembach; Amaral, Marcia Franz. Estilo de vida e Identidade Juvenil: a revista Capricho sob uma perspectiva atual. In: Congresso de Ciências da Comunicação na Região Sul, 10. Blumenau. Anais...: Intercom-Sociedade Brasileira de Estudos Interdisciplinares de Comunicação, maio/2009. P.1-12.

GOHN, Maria da Glória. Educação não-formal, participação da sociedade civil e estruturas colegiadas nas escolas. Ensaio: aval.pol.públ.Educ., Rio de Janeiro, v. 14, n. 50, Mar. 2006. Available from <http://www. scielo.br/scielo.php?script=sci_arttext\&pid=S0104-40362006000100003\&lng=en\&nrm=iso $>$. Acesso em: 07 de junho de 2013. http://dx.doi.org/10.1590/S0104-40362006000100003.

HEILBORN, M. L.; Cabral, C. S. \& Bozon, M. Valores sobre sexualidade e elenco de práticas: tensões entre modernização diferencial e lógicas tradicionais. In: Heilborn, M. L.; Aquino, E. M. L.; Bozon, M. \& Knauth, D. R. (orgs.). O aprendizado da sexualidade: reprodução e trajetórias sociais de jovens brasileiros (pp. 207-266). Rio de Janeiro: Garamond e Fiocruz (2006).

,“Corpo, Sexualidade e Gênero”, in: DORA, Denise Dourado(org.), Feminino Masculino-igualdade e diferença na justiça. Porto Alegre:Editora Salina, 1997, p.47-57.

,Entre as tramas da sexualidade brasileira. Revista Estudos Feministas, Florianópolis, 14(1): 336, janeiro-abril/2006.

LE BRETON, David. A sociologia do corpo. 5.ed. Petrópolis, RJ: Vozes, 2011.

LOURO, Guacira Lopes. Pedagogias da Sexualidade. In:.O corpo Educado: Pedagogias da Sexualidade, In: Louro, Guacira Lopes (Org.); Tradução dos artigos: Tomaz Tadeu da Silva. Belo Horizonte: Autêntica Editora; 2010, p.07-34.

MARTÍN-BARBERO,Dos Meios às Mediações: Comunicação, cultura e hegemonia. 2.ed.Rio de Janeiro: Editora UFRJ, 2003.

América Latina e os Anos Recentes: O Estudo da Recepção em Comunicação Social. In: SOUZA, Mauro Wilton de.(org). Sujeito, O Lado Oculto do Receptor.São Paulo. Editora Brasiliense S.A. 1995. Pag.39-70.

MIRANDA-RIBEIRO, P.; Moore, A. Já nas bancas: a saúde reprodutiva das adolescentes vista através das revistas Querida e Capricho. Revista Brasileira de Estudos da População, V,19.n.2, Jul/dez.2002.

PALHARES, José Augusto. Reflexões sobre o não-escolar na escola e para além dela.Rev. Port. de Educação, Braga, (2009). Disponível em <http://www.scielo.gpeari.mctes.pt/scielo.php?script=sci_arttext\&pid=S087191872009000200004\&lng=pt\&nrm=iso>. Acesso em 22 jul. 2013.

PUBLIABRIL. EditoraAbril.SãoPaulo. Disponível em: http://www.publiabril.com.br/marcas/capricho/revista/ informacoes-gerais. (2006). Acesso em, 15 de fevereiro de 2012.

REVISTA ATREVIDA. Editora Escala: São Paulo, n¹98, Fevereiro, 2011.

REVISTA ATREVIDA. Editora Escala: São Paulo, nº199, Março, 2011.

REVISTA ATREVIDA. Editora Escala: São Paulo, n²01, Maio, 2011.

REVISTA CAPRICHO. Editora Abril: São Paulo, n¹114, Janeiro, 2011.

REVISTA CAPRICHO. Editora Abril: São Paulo, n¹118, Março, 2011. 
ROHDEN, Fabíola. Gênero, sexualidade e raça/etnia: desafios transversais na formação do professor. Cadernos de Pesquisa, São Paulo, v. 39, n. 136, p. 157-174, jan./abr. 2009.

SANTOS, Daniela Barsotti. Ideais de mulher: Estética, visão de corpo e de relações afetivo-sexuais veiculados pela mídia escrita em revistas direcionadas ao público jovem no contexto brasileiro. Ribeirão Preto, 2006. Disponível em <http://www.teses.usp.br/teses/disponiveis/59/59137/tde-07022007-51910/publico/ DissertacaoDanielaBarsottiSantos.pdf> Acesso em: 15, fevereiro, 2012.

WEEKS, Jeffrey. “O Corpo e a Sexualidade” In Louro, Guacira Lopes (Org.), O corpo Educado: Pedagogias da Sexualidade, Tradução dos artigos: Tomaz Tadeu da Silva. Belo Horizonte: Autêntica Editora; 2010, p.35-82. 